\title{
STUDY OF BIODIVERSITY OF ARBUSCULAR MYCORRHIZAL FUNGI IN ADDITION WITH DIFFERENT ORGANIC MATTER IN DIFFERENT SEASONS OF KAVRE DISTRICT (CENTRAL NEPAL)
}

\author{
Geeta Shrestha Vaidya*, Keshab Shrestha**, Buddhi R. Khadge***, \\ Nancy C. Johnson ${ }^{* * * *}$ and Håkan Wallander***** \\ *Nepal Academy of Science \& Technology (NAST),. Khumaltar, Nepal. \\ **Natural History Museum, Swayambhu, Kathmandu, Nepal. \\ ****Plant Pathology Division, Nepal Agriculture Research Council, Khumaltar, Nepal. \\ ****Environmental and Biological Sciences, Northern Arizona University, Flagstaff, AZ 86011-5694, USA. \\ *****Department of Microbial Ecology, Ecology Building, Lund University, SE-223 62 Lund, Sweden.
}

\begin{abstract}
Different types of organic matter (dried and powdered 5 gms. leaves of Tithonia diversifolia, Eupatorium adenophorum, Lantana camara, farmers compost) and triple-superphosphate were mixed with eroded soil collected from sites with no vegetation. Eroded soil without amendments served as control. The mixture was placed in mesh bags (50 Mm mesh) that allowed fungal colonization but excluded roots. Two sets of mesh bags were buried around Bauhinia purpurea and Leucaena diversifolia that had been planted in an eroded site. The first set was buried in June 2003 and harvest in December 2003 (the monsoon period) and the second set was buried in December 2003 and harvested in June 2004 (The drier period). We found that more Arbuscular mycorrhizal (AM) fungal biomas and spores were produced during the wet season than during the dry season. The different types of organic matter had similar influence on the amount of AM biomass but the species composition was varied with the types of organic matter. In wet season nine species of AM spores and in dry season ten species of AM spores were found. In dry season Scutellospora nigra was found which was different from wet season.
\end{abstract}

Key words: Arbuscular mycorrhiza; Organic matter; Wet season; Dry season.

\section{INTRODUCTION}

Nepal is very prone to soil erosion and is susceptible to sediment disasters mainly caused by slope failure, land slides, debris and bank erosion. There is an urgent need to control erosion and prevent potential sediment disaster in Nepal (Shrestha Vaidya et al. 2002). Therefore mycorrhizae are essential for the establishment of tree seedlings and for their good growth and development in soils in low nutrients.

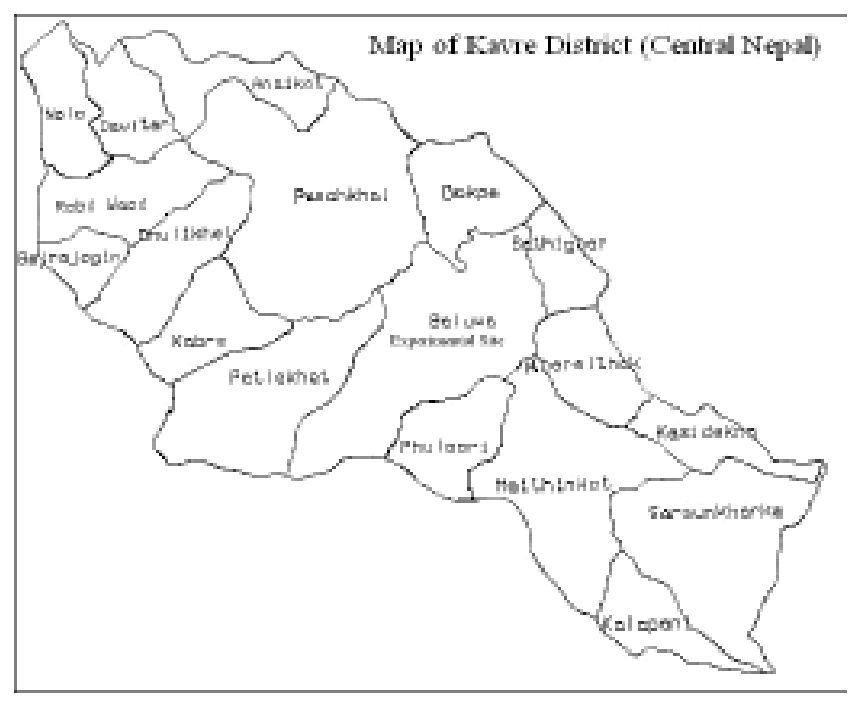

Because mycorrhizae is beneficial to tree growth as they increase nutrient uptake and expose a greater absorbingsurface (Shrestha Vaidya et al. 2002 and 2005).

The arbuscular mycorrhizal (AM) symbiosis is an association between most terrestrial plants and a class of fungi (Glomeromycota) which occurs in the roots of host plants (Schussier et al. 2001). AM fungi are normally considered to improve plant mineral nutrition( in particular phosphorus (P), water uptake, and resistance to root pathogens (Smith \& Read 1997).

Addition of organic matter such as green manure is a common practice to improve soil nutrient content and soil structure . Organic residues from plants such as Tithonia diversifolia and Lantana camara have been found to be especially beneficial since they are reported to have a high content of $\mathrm{N}$ and $\mathrm{P}$, which is mineralized rapidly from the organic material. Nziguheba et al. (2000) found that $\mathrm{P}$ is released more rapidly from such organic residues than from triple superphosphate.

Successful colonization by mycorrhizal fungi is especially important in degraded soils where nutrient availability is low; furthermore, AM fungi improve soil structure because they produce extraradical hyphal networks and their hyphae contain and release glomalin, which is a putative glycoprotein, assayed from soil as glomalin-related soil

Author for Correspondence: Geeta Shrestha Vaidya, Nepal Academy of Science \& Technology (NAST),. Khumaltar, Nepal. Email: geetashrestha1@hotmail.com. 
protein (GRSP) that is correlated with aggregate water stability (Wright \& Upadhyaya 1998, Rillig 2004; Rillig \& Mummey 2006). Improved soil structure increases water infiltration and can reduce soil erosion (Tisdall \& Oades 1982).

Many biotic and abiotic factors influence growth and biomass partitioning of AM fungi. Farming systems (Boddington \& Dodd, 2000), soil moisture (Anderson et al. 1983), organic matter (Ryan et al. 1994), pH (Porter et al. 1987; van Aarle et al. 2002) and temperature (Koske 1987) are all examples of factors that can influence the distribution of AM fungal hyphae and spores. Managing soil could thus be a potential way to optimise proliferation of indigenous AM fungi (Boddington \& Dodd 2000). Particularly, addition of organic matter can have a beneficial effect on the growth of indigenous AM fungi in nutrient-limited soils (Caravaca et al. 2002; Gaur \& Adholeya 2002). Organic amendments enhance spore production (Johnson \& McGraw 1988; Douds et al. 1997), extra radical proliferation of hyphae (St. John et al. 1983; Joner \& Jakobsen, 1995), and improve colonization of roots (Muthukumar \& Udaiyan 2000). Giovanetti \& Avio (1985) suggested that this beneficial effect might be related to increased pore volume in soil which has a beneficial effect on AM colonization, the mycorrhizal growth response and AM spore numbers. Furthermore, Ryan et al. (1994) attribute increased AM fungal biomass to the beneficial effects of organic matter on soil structure, water status, and on synergistic microbial activities in the soil. Organic matter addition to the soil in eroded sites could thus be an approach to enhance the beneficial effect of AM fungi on soil stabilization and plant establishment.

\section{MATERIAL AND METHODS}

This field experiment was conducted in Baluwa Forest Kavre district in Central Nepal.

This forest is situated $40 \mathrm{~km}$ East of Kathmandu city on the side of Arniko highway to the Tibetan border. The study site was completely eroded as a result of a land slide in 1998 it was planted with Bauhinia purpurea and Leucaenia diversifolia which both are important fodder plants in Nepal. The Fodder department of the National Agriculture Research Council, Khumaltar, Nepal, performed Plantation. At the time of our experiment approximately $30 \%$ of the plants had survived. The soil at the experimental site is in this area are dominated by Rhodustults and Hapolustults (both members of the Ultisols soil order) (Brown et al. 2000). The chemical characteristics of the soil have been examined earlier by the Division of Soil Science, Nepal Agricultural Research Council (NARC). It was found that the soil was acidic ( $\mathrm{pH} \mathrm{4.0)}$ and poor in nutrients and in organic matter. The total content of $\mathrm{N}$, measured by the Kjelldahl method, was $4.1 \mathrm{mg} \mathrm{g}^{-1}$ and the organic matter content was $0.73 \%$. The low $\mathrm{pH}$ and the high content of $\mathrm{Al}$ and $\mathrm{Fe}$ in these soils suggest a very high $\mathrm{P}$ fixing capacity G.Shrestha Vaidya et.al 2007).

\section{Experimental design and methods}

Growth of AM fungi under field conditions was estimated with in-growth mesh bags, similar to a design used earlier to estimate growth of mycorrhizal fungi in forests (Wallander et al. 2001), sand dunes (Olsson \& Wilhelmsson 2000), (G.Shrestha Vaidya et.al 2007) and pre-Saharan desert shrubland ecosystems (Labidi et al. 200x). The mesh bags were constructed of nylon mesh (50 $\mu \mathrm{m}$ mesh size) to allow fungal colonization but excluded roots, because the latter cannot penetrate the mesh. These bags were used to clearly separate hyphal from root effects in the field. The mesh bags were filled with eroded soil mixed with different forms of organic matter or rock phosphate (see below).

The eroded soil was collected from a degraded site at Bisankhu Narayan (Godavari) in Nepal. This site was completely eroded due to a landslide after heavy rainfall and no vegetation was present on the site. Forty-five g of eroded soil were placed in nylon mesh bags and mixed with different types of organic matter or left unmixed as control: 5 gms. of dried leaves or dried compost (10\% by weight) was used as organic matter additions. Fully expanded leaves of three common agroforestry plant species (Tithonia diversifolia, Lantana camara and Eupatorium adenophorum) were collected from border rows in a farmer's fields and from roadsides and the compost were collected from a local farmer. The compost was made from disposed vegetable waste, cow dung, straw and husk. One of the treatment Triplesuperphosphates. In this case $45 \mathrm{mg}$ Trple-superphosphate was mixed with $50 \mathrm{~g}$ of eroded soil. This represents approximately 40 - $50 \mathrm{~kg} \mathrm{P}$ per hectare which is an amount usually used by local farmers. The mesh bags that were used as controls were filled with 50 gms. of eroded soil without any amendments. In total, 6 treatments were included (control, Tithonia diversifolia, Lantana camera, Eupatorium adenophorum, compost and Triple-superphosphate).

The experiment lasted for one year: one set of mesh bags was buried from June 2003 through December 2003 (the monsoon period) and a second set was buried in the same locations from December 2003 through June 2004 (the dry period). During the dry period some rain was recorded in January (23 days) and some rain was recorded in June (2-3 days). Plenty of rain was recorded during the wet season although no estimates of the amounts were made. Mesh bags containing each of the six treatments were buried $10 \mathrm{~cm}$ from the base of eight Bauhinia purpurea trees and eight Leucaena diversifolia trees (approximately 1.5-2m high) for a total of eight replicates in each tree species. A total of 192 bags were used (2 harvests x 6 treatments x 2 tree species x 8 replicates). Spore production differed between tree species and the tree species are therefore separated in the spore analysis. The mesh bags were buried to a depth of about $10 \mathrm{~cm}$ where the density of roots was high (Shrestha Vaidya et.al. 2007).

\section{Elemental analysis of Plant and Soil material}

The fresh leaves of the plant species were air dried and ground to pass a $0.5 \mathrm{~mm}$ sieve. The Concentrations of $\mathrm{Al}, \mathrm{Ca}$, $\mathrm{Cu}, \mathrm{Fe}, \mathrm{K}, \mathrm{Mg}, \mathrm{Mn}, \mathrm{Na}, \mathrm{P}, \mathrm{S}$, and Zn of dried plant leaves, dried compost and eroded soil were analyzed with ICP-AES. The $\mathrm{C}$ and $\mathrm{N}$ were analyzed with an elemental analyzer (Elementar Analysensysteme GmbH. Modell vario MAX CN.). 
Table 1: Chemical composition $\mathrm{mg} \mathrm{g}^{-1}$ of the eroded soil and the different organic amendments used in the mesh bags. Values are one measurement of a pooled and well-mixed sample of each substrate.

\begin{tabular}{|l|l|l|l|l|l|l|l|l|l|l|l|}
\hline Sample type & C & N & P & C:N & C:P & K & Ca & Mg & S & Al & Fe \\
\hline Thitonia diversifolia & 441 & 33.2 & 2,8 & 13.2 & 158 & 34.1 & 13.4 & 3.1 & 1.8 & 0.2 & 0.2 \\
\hline Lantana camara & 414 & 28.6 & 1.7 & 14.5 & 243 & 12.2 & 26.3 & 2.9 & 2.6 & 0.7 & 0.6 \\
\hline Eupatorium adenephorum & 464 & 36.7 & 2.6 & 12.6 & 178 & 22.6 & 14.8 & 2.2 & 2.0 & 0.5 & 0.6 \\
\hline Farmers Compost & 247 & 22.3 & 17.6 & 11.0 & 14.0 & 14.7 & 15.5 & 11.8 & 4.1 & 2.2 & 2.8 \\
\hline Eroded Soil & 1.4 & 0.11 & 0.3 & 12.4 & 0.4 & 1.0 & 1.1 & 0.6 & 0.03 & 12.5 & 42.3 \\
\hline
\end{tabular}

\section{Spore analyses}

The AM fungal spores within $25 \mathrm{~g}$ of the soil and amendment mixtures inside the mesh bags were extracted, identified and quantified. Spores were extracted using wet sieving and sucrose centrifugation (McKenney \& Lindsey 1987). Spores were mounted in polyvinyl alcohol on slides and examined using a compound microscope. Species were identified to species using taxonomic characteristics described on the INVAM website (http://invam.caf.wvu.edu/) and Schenck \& Perez (1990). Several spore samples from the first harvest were lost, especially from the plots with Leucaena diversifolia trees. In total 43 spore analysis were analysed from the first harvest (wet season) and 96 from the last harvest (dry season) (G.Shrestha Vaidya et.al 2007). The potential to find effects of the different organic material on spore composition is therefore smaller for the first harvest compared to the second harvest.

Analysis of Endomycorrhizal Fungi (AM spores) in different seasons

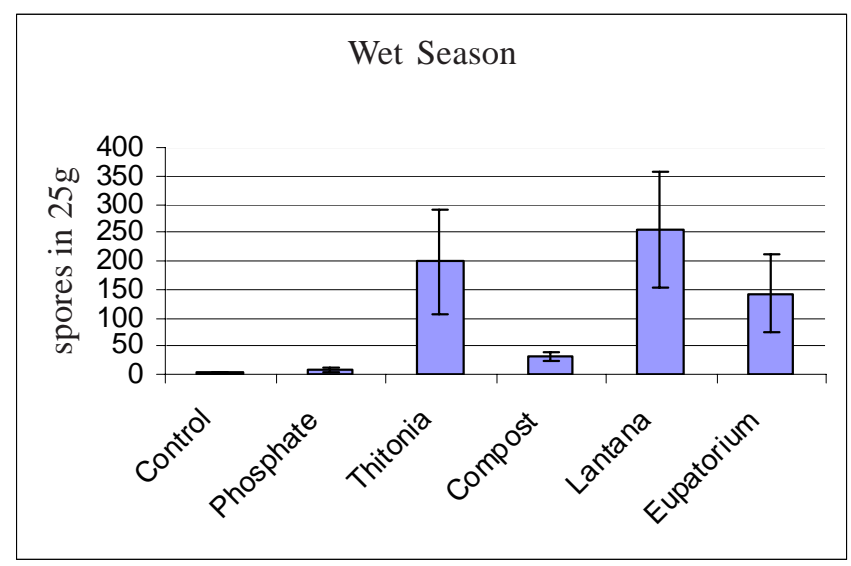

Fig. 1

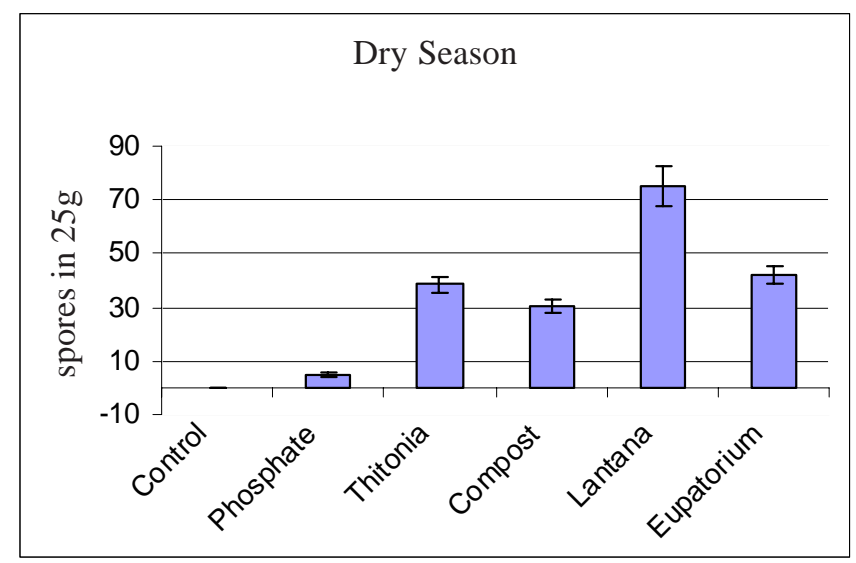

Fig. 2
Analysis of different Endomycorrhizal Fungi (AM spores) in different organic matter

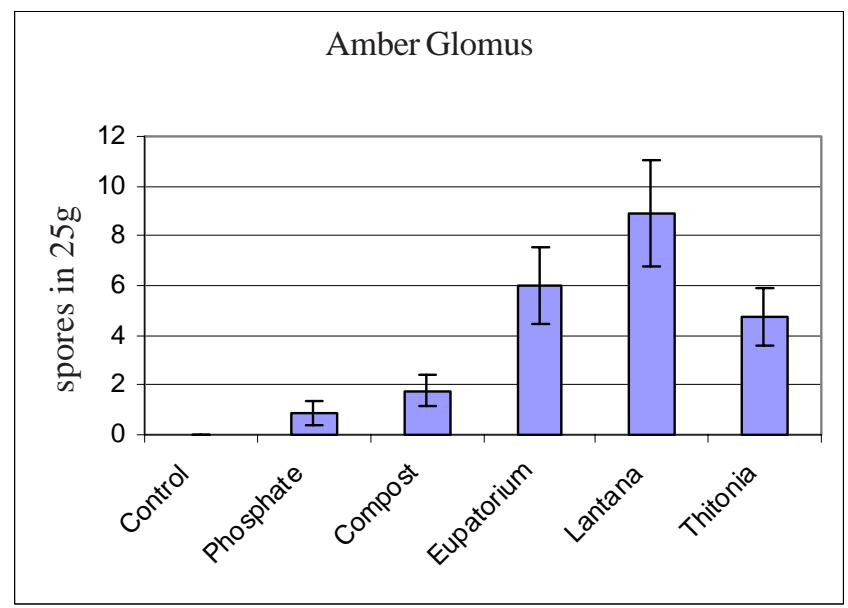

Fig. 3

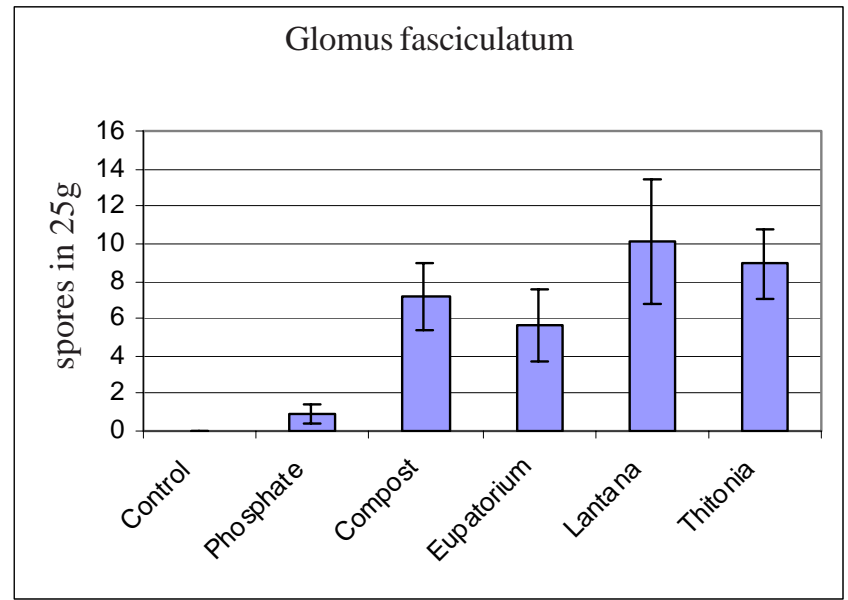

Fig. 4

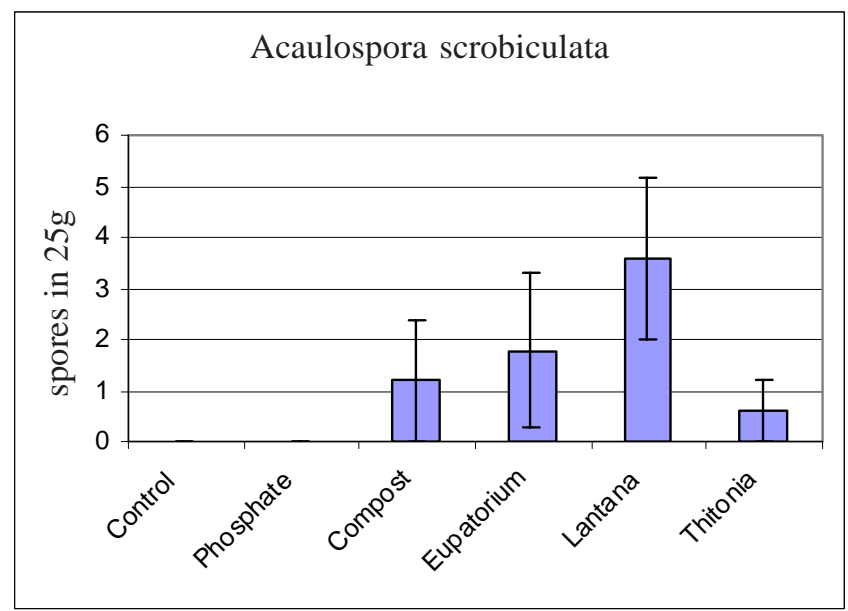

Fig. 5 


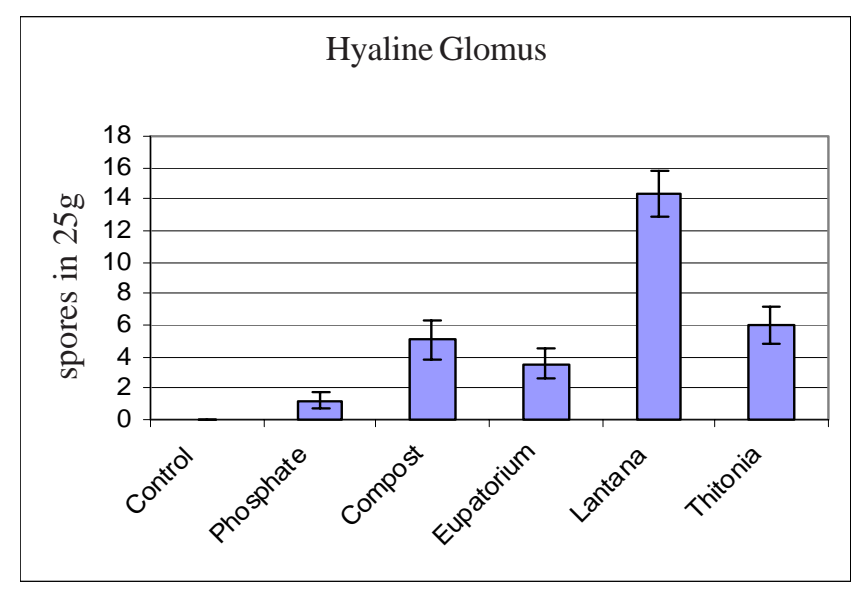

Fig. 6

Glomus aggregatum

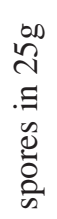

Fig. 7

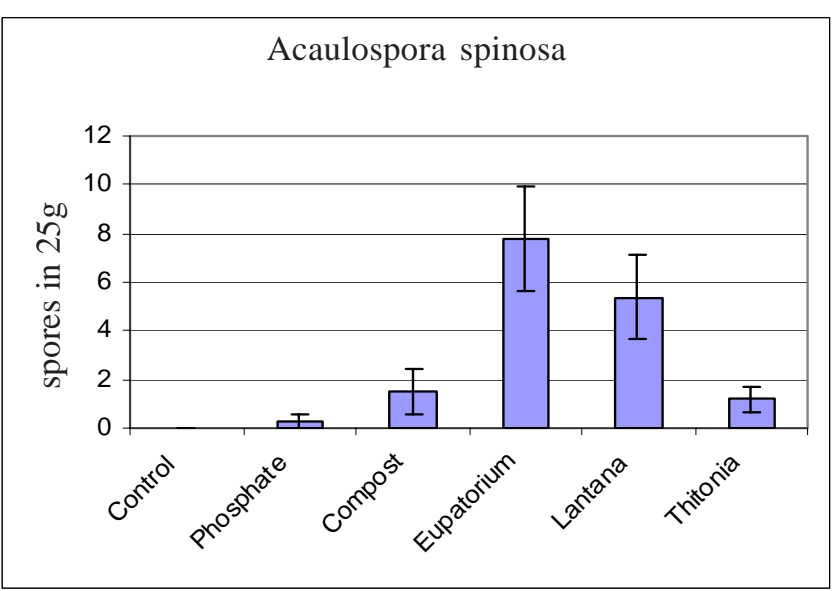

Fig. 8

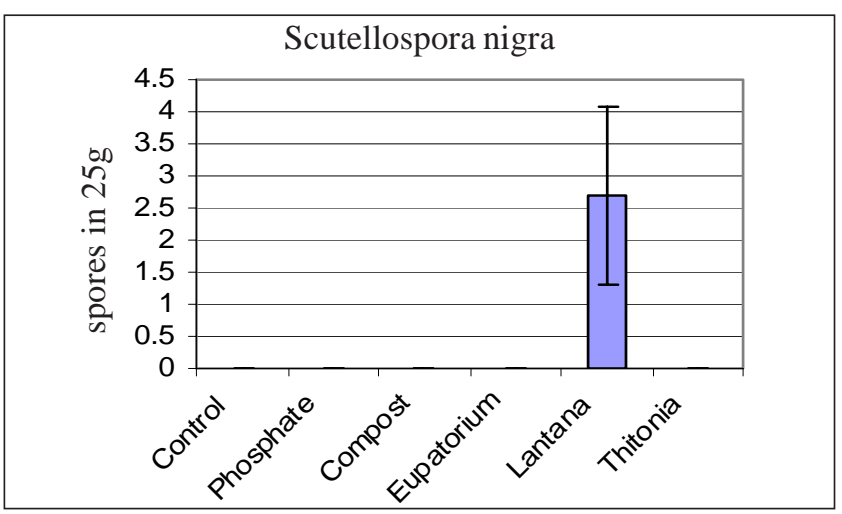

Fig. 9

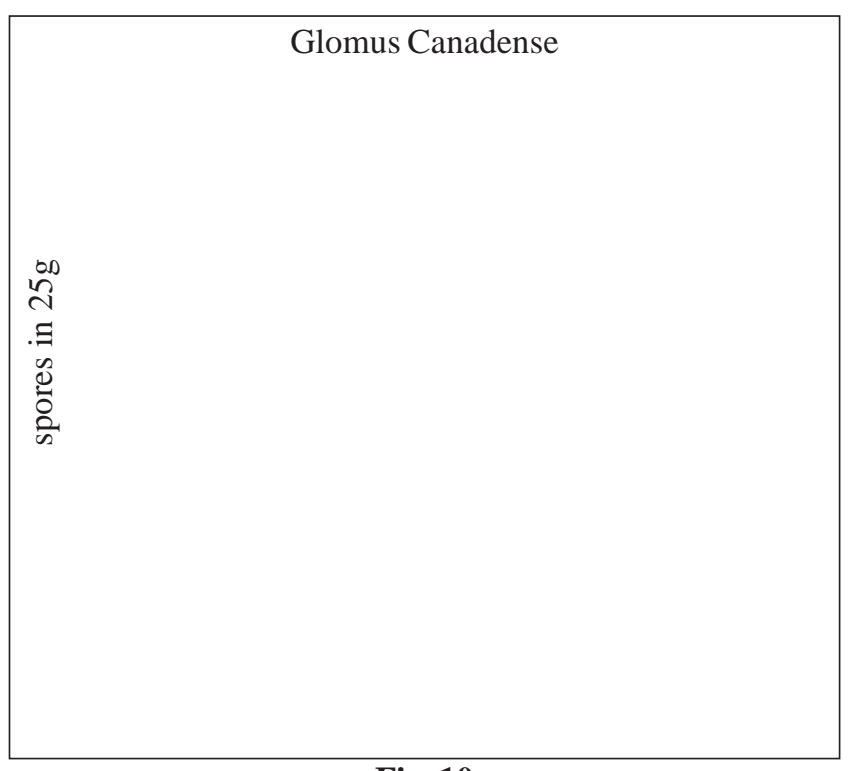

Fig. 10

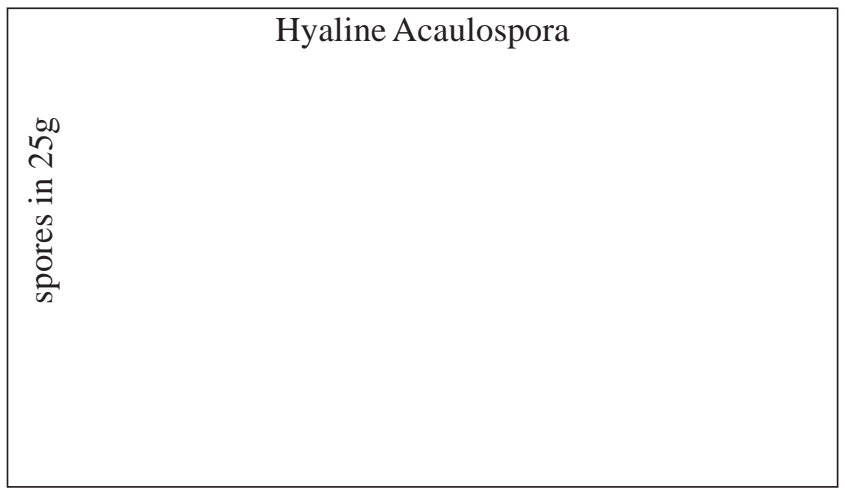

Fig. 11

\section{RESULTS}

The eroded soil that was used in the mesh bags had extremely low levels of C, N, P, K, Ca, and Mg and high levels of Fe and $\mathrm{Al}$. The dried leaf material from the three agro forestry species that was used as organic amendments in the mesh bags differed somewhat in chemical content (Table 1). Eupatorium and Tithonia appeared to be more similar while Lantana had lower $\mathrm{N}$ and $\mathrm{P}$ content. The compost had considerably higher P content than the dried leaf material (Table 1).

The compost contained much more $\mathrm{P}$ than the leaves from the agro forestry plants AM fungi produces significantly lower amounts of spores in the mesh bags with compost compared to the other treatments, which may indicate that spore formation was inhibited by the high $\mathrm{P}$ level in the compost. We found no effect of triple-superphosphate addition and the effect of triple-superphosphate addition on spore formation cannot be evaluated since spore formation in mesh bags without organic matter addition was almost absent. More spores were found in wet season than dry season but in dry season one species Scutellospora nigra was found but not found in wet season. In both seasons number of spores is more in Lantana camara than other organic matter (Fig.1 \& Fig. 2). The different number of AM spores in different organic matter was found different in number ( Fig. 3 to Fig. 11). The addition of compost or green 
manure is an important way to improve the soil in degraded areas since nitrogen and other nutrients, as well as organic matter which improves soil structure, is added with the organic material (Caravaca et al. 2002; Muthukumar \& Udaiyan, 2000, Nziguheba et al. 2000).

\section{DISCUSSION}

The use of in-growth mesh bags was found to be a successful way of measuring recently produced AM fungal biomass and spores in eroded slopes of Nepal vegetated with Bauhinia purpurea and Leucaena diversifolia. Other methods for estimating biomass of AM fungi in soil such as extraction of hyphae or spores (Boddington \& Dodd 2000) or estimates of biochemical markers directly in soil samples (Olsson et al. 1999) includes an unknown fraction of dead or inactive AM biomass. The production of recently formed extra radical AM mycelia is an important parameter since it can be directly related to the capacity of the plants to take up nutrients and to improvements of the soil structure and stability in degraded soils.

Similar results were found by adding compost made of Acacia cyanophylla leaves to eroded soil in Acacia tortilis savanna in pre-Saharan areas in Tunisia (Labidi et al. 2006). The positive effect of organic matter addition on AM growth could be an effect of higher humidity in mesh bags with organic amendments, since the addition of organic matter has a beneficial effect on soil structure and water-holding capacity (Ryan et al., 1994). The added organic matter could also increase the soil porosity and decrease the mechanical soil resistance to the growth of AM hyphae (Joner \& Jakobsen, 1995).

Improved nutrient and water uptake by the planted trees can be expected in response to better AM growth and the positive effect on the growth of AM fungi is in good and found that organic matter addition increased AM fungal hyphal growth (Labidi et al 200x; Nicolson 1959; Koske et al. 1975; Joner \& Jakobsen, 1995) and AM spore formation (Douds et al. 1997; Baby \& Manibhushanrao 1996; Muthukumar \& Udaiyan, 2000; Gryndler et al. 2002; Harinikumar \& Bagyaraj 1989; Jamil Mohammed et al. 2003; Jeffries \& Barea (2001). In addition, St John et al. (1983), Frey \& Ellis (1997) and Friberg (2001) found that AM fungal hyphae grew best in soils with a high amount of organic matter. The highest VAM fungal population was recorded in November and decreased thereafter. The low VAM fungal population in January and February could be due to low soil moisture (Khadge 1988). Same way in our study also we got more spores in wet season than dry season.

The present study provides the first information on a stimulating effect of organic material addition on extra-radical growth of AM fungi in eroded slopes in Nepal (G.Shrestha Vaidya et.al 2007). These results show that organic matter addition can improve AM spores as well as plant survival in such areas.

\section{ACKNOWLEDGEMENT}

We would like to thank the Swedish International Development Cooperation Agency, the National Science Foundation (DEB 0316136), and we are grateful to Dr.D.P.Serchan , Chief of Soil science Department, NARC for providing Tithonia samples and also thanks to Dr. Pariyar chief of fodder Department, NARC . Our spécial thanks goes to Mr. Purna Bahadur Tamang, Lab assistant of NAST.

\section{REFERENCES}

Anderson, R.C., Liberta, A.E., Dickman, L.A. and Katz, A.J. 1983. Spatial variation in vesicular arbuscular mycorrhiza spore density. Bulletin of the Torrey Botanical Club 110:519-525.

Baby, U.I. and Manibhushanrao, K. 1996. Influence of organic amendments on arbuscular mycorrhizal fungi in relation to rice sheath blight disease. Mycorrhiza. 6:201-206.

Boddington, C.L. and Dodd, J.C. 2000. The effect of agricultural practices on the development of indigenous arbuscular mycorrhizal fungi. I. Field studies in an Indonesian ultisol. Plant and soil. 218:137-144.

Brown, S., Schreier, H. and Shah, P.B. 2000. Soil phosphorus fertility degradation: A geographic information system-based assessment. Journal of Environmental Quality. 29:1152-1160.

Caravaca, F.J., Barea, M. and Roldán, A. 2002. Synergistic influence of an arbuscular mycorrhizal fungus and organic amendment on Pistacia lentiscus L. seedlings afforested in a degraded semi-arid soil. Soil Biology and Biochemistry. 34:1139-1145.

Douds, D.D., Galvez, L., Franke-Snyder, M., Reider, G. and Drinkwater, L.E. 1997. Effect of compost addition and crop rotation point upon VAM fungi. Agriculture, Ecosystems ands Environment. 65:257-266.

Frey, J.E. and Ellis, J.R. 1997. Relationship of soil properties and soil amendments to response of Glomus intraradices and soybeans. Canadian Journal of Botany. 75:483-491.

Friberg, S. 2001. Distribution and diversity of arbuscular mycorrhizal fungi in traditional agriculture on the Niger inland delta, Mali, West Africa. CBM:s Skriftserie. 3:53-80.

Giovanetti, M. and Avio, L. 1985. VAM infection and reproduction as influenced by different organic and inorganic substances. In proceedings of the $6^{\text {th }}$ NorthAmerican Conference on Mycorrhizae (R.Molina. Ed.) Forest Research Laboratory. Bend, Oregon.

Gaur, A. and Adholeya, A. 2002. Arbuscular-Mycorrhizal inoculation of five tropical fodder crops and inoculum production in marginal soil amended with organic matter. Biology and Fertility of Soils. 35:214-218.

Gryndler, M., Vosátka, M., Hršelová, H., Chvátalová, I. and Jansa, J. 2002. Interaction between arbuscular mycorrhizal fungi and cellulose in growth substrate. Applied Soil Ecology. 19:279 288.

Harinikumar, K.M. and Bagyaraj, D.J. 1989. Effect of cropping sequence, fertilizers and farmyard manure on vesicular-arbuscular mycorrhizal fungi in different crops over three consecutive seasons. Biology and Fertility of Soils. 7:173-175.

Jamil Mohammed, M., Rushdi Hamad, S. and Issa Malkawi, H. 2003. Population of arbuscular mycorrhizal fungi in semi arid environment of Jordan as influenced by biotic and abiotic factors. Journal of Arid Environments. 53:409 417. 
Jeffries, P., and Barea, J.M. 2001. Arbuscular Mycorrhiza- a Key Component of Sustainable Plant- Soil Ecosystems. In: The Mycota A Comprehensive Treatise on Fungi as Experimental Systems for Basic and Applied Research. Ed. Springer- Verlag Berlin Heidelberg. 95-108.

Johnson, N.C., and McGraw, A.C. 1988. Vesicular-arbuscular mycorrhizae in taconite tailings II. Effects of reclamation practices. Agriculture Ecosystems and Environment 21:143-152.

Joner, E.J. and Jakobsen, I. 1995. Growth and extra cellular Phosphatase activity of arbuscular mycorrhizal hyphae as influenced by soil organic matter. Soil Biology and Biochemistry 27:1153-1159.

Khadge Buddhi, R .1988. Vasicular-Arbuscular Mycorrhizae (VAM) in a Tropical Cropping System: Effect of Cropping Pattern and Response of Some Field crops. Ph.D. Thesis. Pp.104.

Koske, R.E. 1987. Distribution of VA mycorrhizal fungi along a latitudinal temperature gradient. Mycologia. 79:55 68.

Koske, R.E., Sutton, J.C. and Sheppard, B.R. 1975. Ecology of Endogone in Lake Huron sand dunes. Canadian Journal of Botany. 53:87-93.

Labidi, S., Nasr, H., Zouagui, M. and Wallander, H. 200x. Effects of compost addition on extra-radical growth of arbuscular mycorrhizal fungi in Acacia tortilis sp. raddiana savanna in a pre-Saharan area. Applied Soil Ecology (accepted)

McKenney, M.C., and Lindsey, D.L. 1987. Improved method for quantifying endomycorrhizal fungi spores from soil. Mycologia 79:779-782.

Muthukumar, T., and Udaiyan, K. 2000. Influence of organic manures on arbuscular mycorrhizal fungi associated with Vigna unguiculata (L.) Walp. In relation to tissue nutrients and soluble carbohydrate in roots under field conditions. Biology and Fertility of Soils 31:114-120.

Nicolson, T.H. 1959. Mycorrhizae in the gramineae. I. Vesiculararbuscular endophytes, with special reference to the external phase. Transactions of the British Mycological Society. 42:421-438.

Nziguheba, G., Merckx, R., Palm, C.A. and Rao, M.R. 2000. Organic residues affect phosphorus availability and maize yields in a Nitisol of Western Kenya. Biology and Fertility of Soils 32:328339.

Olsson, P.A. and Wilhelmsson, P. 2000. The growth of external AM fungal mycelium in sand dunes and in experimental systems. Plant and Soil. 226:161-169

Porter, W.M., Robsen, A.D. and Abott, L.K. 1987. Field survey of the distribution of vesicular arbuscular mycorrhizal fungi in relation to soil pH. Journal of Applied Ecology. 24:659 662.

Rillig, M.C. 2004. Arbuscular mycorrhizae, glomalin, and soil aggregation. Canadian Journal of Soil Science. 84:355-363.
Rillig, M.C. and Mummey, D.L. 2006. Tansley review: Mycorrhizas and soil structure. New Phytologist (in press).

Ryan, M.H., Chilvers, G.A. and Dumaresq, D.C. 1994. Colonisation of wheat by VA- mycorrhizal fungi was found to be higher on a farm managed in an organic manner than on a conventional neighbour. Plant and Soil. 160:33-40.

Schenck, N.C. and Perez, Y. 1990. Manual for the identification of VA mycorrhizal fungi. Synergistic Publications, Gainesville, Florida, USA.

Schussler A., Schwartzzott D. \& Walker C. (2001). A new phylum, the Glomeromycota: phylogeny and evolution. Mycological Research 105: $1413-1421$.

Shrestha Vaidya, Geeta and Sujan, Piya. 2002. Study of Antagonistic Action of Two ectomycorrhizal fungi isolated from Pine forest of Dadeldhura. Proc. International Seminar on Mountain, March. 6-8: $571-577$.

Shrestha Vaidya, Geeta, Shrestha, K. and Wallander, H. 2005. Antagonistic Study of Ectomycorrhizal Fungi Isolated from Baluwa Forest (Central Nepal) against with pathogenic Fungi and Bacteria. Scientific World. 3(3):49-52.

Shrestha Vaidya, G., Shrestha, K., Wallander, H. and Khadge, B.R. 2006. Study of Rhizospheric Microflora of Baluwa Forest of Kavre District (Central Nepal). Scientific World. 4(4): 44-49.

Shrestha Vaidya, G., Shrestha, K., Khadge, B.R., Johnson, N.C. and Wallander, H. 2007. Organic matter stimulates arbuscular mycorrhizal fungi in Bauhinia purpurea and Leucaena diversifolia plantations on eroded slopes in Nepal accepted by Restoration Ecology, UK . in Press.

Smith, S.E. and Read, D.J. 1997. Mycorrhizal symbiosis. Second Edition. Academic Press, London, UK.

St. John, T.V., Coleman, D.C. and Reid, C.P.P. 1983. Association of vesicular- arbuscular mycorrhizal hyphae with soil organic particles. Ecology. 64:957-959.

Tisdall, J.M. and Oades, J.M. 1982. Organic matter and water-stable aggregates in soils. Journal of soil Science. 33:141-163.

Van Aarle, I.M., Olsson, P.A. and Söderström, B. 2002. Arbuscular mycorrhizal fungi respond to the substrate $\mathrm{pH}$ of their extraradical mycelium by altered growth and root colonization. New Phytologist. 155:173-182.

Wallander, H., Nilsson, L.O., Hagerberg, D. and Bååth, E. 2001. Estimation of the biomass and seasonal growth of external mycelium of ectomycorrhizal fungi in the field. New Phytologist. 151:753-760.

Wright, S.F. and Upadhyaya, A. 1998. A survey of soils for aggregate stability and glomalin, a glycoprotein produced by hyphae of arbuscular mycorrhizal fungi. Plant and soil. 198:97-107. Biochemistry (in press). 